\title{
DISSOCIATION OF CARBON LINKS BY MICROWAVE PLASMATIC ENERGY AND POWER FOR WASTE TRANSFORMATION
}

\author{
Fernando Valencia Amador, Ms. ${ }^{1}$, Jaime Luyo Kuong, Phd. ${ }^{2}$, Walter Estrada López, Phd ${ }^{3}$ \\ ${ }^{1}$ Universidad Nacional de Ingeniería, Peru,fvalencia@uni.pe,jeluyo@yahoo.es,westrada@uni.edu.pe
}

\begin{abstract}
Herein, we analyzed the molecular dissociation of carbon links using plasma radiation energy. This is a destructive method that is employed for the disposal of organic waste, particularly those species that have carbon bonds with a toxic nature and negative environmental impact. We evaluated the physical and chemical conditions to break the carbon links and foster molecular interactions into a process that results in either useful products or harmless substances that are disposable. We proposed a novel technique to quantitatively evaluate the reduction in the quantity of carbon bonds in a sample by direct radiation without plasma thermal action. This makes it possible to generate gasification mechanisms that could produce harmless gaseous products in an energy transformation process. Plasma radiation energy production is based on the interaction between microwave radiation passing through absorbing antennas. At high temperatures, a thermal activity occurs during this interaction, with the absorbing antennas acting as electromagnetic sinks and an action-reaction process generating plasma energy that is released to the surroundings as a thermal dart and radiation. Liquid samples under assay was exposed by using plasma radiation component of this source only; passing the sample through a filter simultaneously, in which we introduce the concept of mechanical disaggregating system. This system acts as a digester by transforming carbon molecules and other substances into less polluting compounds. We used a mixture of cyanide dissolved in water as an assay sample, coming from a mine waters, which was subjected to the plasma radiant component and studied this energy generated acting over the purification and transformation of samples.
\end{abstract}

Keywords-- Energy Plasma, Plasma molecular dissociation, Mechanical disaggregating system, Plasma reactor, Cyanide decomposition

\section{INTRODUCTION}

The damage caused by pollution, particularly from the urban industry and the mining sector, are of considerable concern today, indicating the need to prevent or remediate the damage $[1,2]$. Water contamination and solid waste are the main agents of environmental pollution, and waste production in major cities has been found to reach millions of tons per year [3-5]. Landfilling is the main waste disposal method; however, at present, there are no more suitable places for landfilling [68]. One possible method to address this issue is to transform potentially harmful waste products into harmless materials that can be used again. This alternative is extremely important when the method can produce an energy benefit from the waste.

Digital Object Identifier (DOI): http://dx.doi.org/10.18687/LACCEI2018.1.1.429 ISBN: 978-0-9993443-1-6

ISSN: $2414-6390$
One promising alternative is plasma gasification, a hightemperature thermal process in which waste is decomposed into fundamental elements and simple compounds in an anaerobic environment. The waste's organic components are converted into high-quality syngas, which can be transformed into fuel using chemical techniques [9]. Our research is motivated by this idea and aimed at demonstrating the concept by producing thermal energy to use its intrinsic radiation in a microwavegenerated plasma reactor [10], proving our thesis that plasma radiation in suitable release conditions of the compounds in a sample, could destroy bonds of its components easily. This allows us to develop a promising technique that transforms waste products into useful ones and contribute toward reducing environmental contamination [11]. This process is based on the interaction between radiation generated by the plasma source and products that are energetically released from the target sample [12]. In general, identifying energy levels for the materials to be treated is required to transform and recombine them at molecular levels [13]. The aggregation and dissociation energies should be considered in this process in the reactor [14, $15]$.

\section{A. Oxidation of free cyanide with UV irradiation}

The energy required to disaggregate material molecules is much lower than that required to break molecular bonds [15]. It is well known that adding suitable complements to components that are organic species allows the formation of fuel species (Figure 1) [16]. The same system is also suitable for reducing the amount of contaminants in polluted atmosphere media; thus, both energy production and atmosphere cleaning can occur simultaneously through disaggregation, dissociation, and reconformation.

We can illustrate this using an example requiring chemical reconformation. Cyanide $\left(\mathrm{CN}^{-}\right)$is widely used in metal ore processing, gold mining, and chemical and petrochemical industries $[17,18]$. Many methods for eliminating $\mathrm{CN}^{-}$from water have been tested; however, many of them were not able to reduce the $\mathrm{CN}^{-}$concentration to less than $1 \mathrm{ppm}$, which is required by ecological regulations in most countries. One of the most commonly employed techniques for oxidizing $\mathrm{CN}^{-}$is the ultraviolet (UV)/ $\mathrm{H}_{2} \mathrm{O}_{2}$ method, which is based on photocatalysis using UV lamps. The current techniques use narrow spectral band lamps, and we are interested in comparing these techniques with plasma irradiation [19].

16 $^{\text {th }}$ LACCEI International Multi-Conference for Engineering, Education, and Technology: "Innovation in Education and Inclusion", 19-21 July 2018, Lima, Peru. 
According to the following equation, combining $\mathrm{H}_{2} \mathrm{O}_{2}$ and UV light produces hydroxyl radicals:

$$
\mathrm{H}_{2} \mathrm{O}_{2} \stackrel{h v}{\rightarrow} 2 \mathrm{HO}^{\bullet}
$$

Hydroxyls are a free radicals and active oxidizing agents $\left(\mathrm{E}_{0}=2.8 \mathrm{~V}\right)$, and according to the following equation, hydroxyl oxidizes $\mathrm{CN}^{-}$:

$$
\mathrm{CN}^{-}+2 \mathrm{HO}^{\bullet} \rightarrow \mathrm{CNO}^{-}+\mathrm{H}_{2} \mathrm{O}
$$

The oxidation of a metal $\mathrm{CN}^{-}$complex is expressed in the following equations:

$$
\begin{gathered}
\mathrm{Me}\left(\mathrm{CN}_{x}\right) \mathrm{y} \stackrel{h v}{\rightarrow} \mathrm{Me}(\mathrm{CN})_{x} y^{*} \\
\mathrm{Me}(\mathrm{CN})_{x}^{y-^{*}}+\mathrm{H}_{2} \mathrm{O}_{2} \rightarrow_{x} \mathrm{CNO}^{-}+\mathrm{Me}(\mathrm{OH})_{z}
\end{gathered}
$$

This method shows the reaction that occurs during water detoxification when a UV lamp - usually at a wavelength of $470 \mathrm{~nm}$ - is used. This process is slow and incomplete when the $\mathrm{H}_{2} \mathrm{O}_{2}$ concentration is insufficient and a water stream is present; therefore, this technique requires a complementary reactive process to achieve its objective $[17,19,20]$.

When these reactions are complemented by electrolysis, this process obtains $\mathrm{CO}_{2}$ and $\mathrm{NH}_{4}{ }^{+}$, otherwise when oxidation is followed, it reacts to nitrogen and $\mathrm{CO}_{2}$. Herein, based on a plasma reactor model, we present an alternative method that can transform toxic waste materials into harmless materials and produce useful energy at the same time.

\section{B. Process in the reactor}

Figure 1 shows a schematic of the proposed plasma reactor model. The final product of the process does not itself become a combustible material. Instead, it will simply be a process of transformation of a raw material in the reactor. Obtaining both transformed waste and combustible products requires energy from an external source at the beginning. The strategy in this case involves quantifying the raw material's aggregation energy and comparing against the dissociation energy of the fundamentals parts [21] and, of course, combine the correct primary raw material. Recombining the dissociated products generates both treated waste and a combustible material, and in principle, one could have a reactor that supplies its own energy [16].

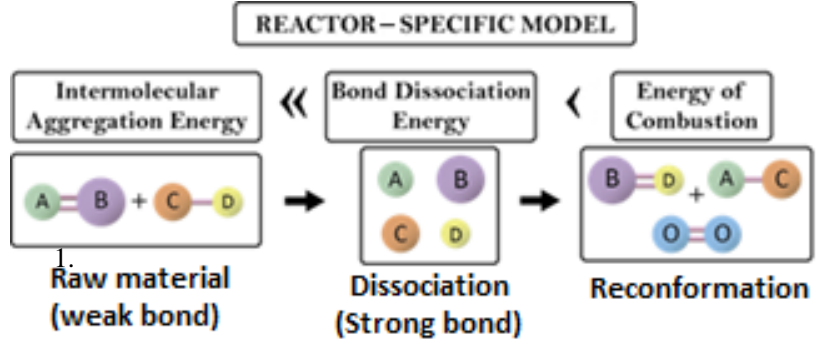

Fig. 1 This scheme shows the sequence for transforming raw materials into treated waste and fuel products when there are carbon species. A, B, D are the raw materials and $\mathrm{C}$ is the carbon bond species. The $\mathrm{A}-\mathrm{C}$ fuel product is exposed to $\mathrm{O}_{2}$. Generally, A represents a hydrogen component.
In other words, why spend high-quality plasma energy in disaggregating molecules joined by weak attraction forces? if our main and hardest purpose is to dissociate strong molecular bonds to reconfigure the products and, in this way, obtain elements really required in the formation of fuels. In practice, weak bonding forces for disaggregating molecules could be break with very low temperatures compared with the energy and temperature required to break strong forces for dissociating, which are present in chemical bondings of the compounds as is showed in Fig 1.

Knowledge about the transformation mechanism and the energy each stage requires enables us to the design of a procedure that breaks the bonds between molecules and determine the need for less power to optimize energy resources and achieve reactor ignition until the reactor reaches selfsustenance [22].

A plasma reaction chamber powered by microwaves has a plasma torch, with a thermal capacity that can reach temperatures ranging from $3000{ }^{\circ} \mathrm{C}$ to $20,000{ }^{\circ} \mathrm{C}$ [23, 24]. In our case, we used electromagnetic radiation generated by a plasma source reaching around $6000{ }^{\circ} \mathrm{C}$ confined in a thermally reduced space produced by microwave [10]. This radiation can be represented by the black-body radiation or Planck spectrum at $6000{ }^{\circ} \mathrm{C}$. Because the radiant spectrum has a greater interaction distance than the thermal dart, we required a sequence of experiments to solely measure the indirect processing power produced by thermal radiation and its effects on the raw material.

In general, plasma gasification of waste materials is conducted by directly applying the plasma torch to the sample [25]; however, despite the enormous amount of energy concentrated in a small thermal dart, the chemical transformation and molecular dissociation of waste occur inside the reactor chamber due to various plasma energy features, including darts, accelerated electrons, and black-body radiation alone and in combination of them. These features interact with raw materials with a disaggregation energy lower than the dissociation energy and without previous processing, and it could be transformed into gas easily if it is already efficiently disaggregated.

Some efforts have also been made to improve and reduce the active energy by disaggregating and dissociating raw materials into hydrogen through the electrolysis of water using $\mathrm{TiO}_{2}$ electrodes. These efforts have been reported in various papers [26-28].

\section{EXPERIMENTAL}

\section{A. System setup}

The experimental system basically covers the following: Figure 2 shows a schematic of the reactor system, which includes a microwave plasma generator device, a plasma hybrid

$1^{\text {th }}$ LACCEI International Multi-Conference for Engineering, Education, and Technology: "Innovation in Education and Inclusion", 19-21 July 2018, Lima, Peru. 
filter collector with a perfusion wall which permit to run down a tiny film of water close to the plasma dart, and a sample inlet $\mathrm{CN}^{-}$dissolved in water, which was obtained from both the head and tail of a gold treatment plant, flows through the water feeder.

It must be considered that this configuration of the experiment avoids the direct contact of the thermal flame of the plasma with the sample, making the work of breaking bonds be achieved by the radiant energy of the plasma.

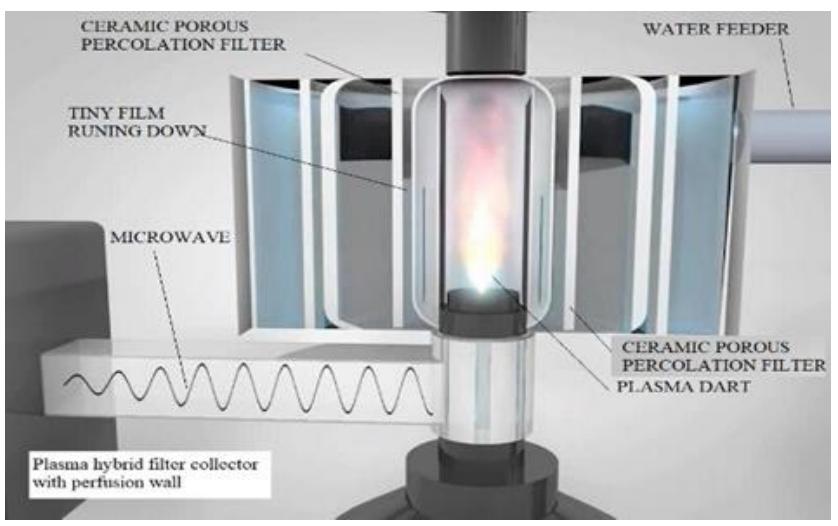

Fig. 2 Device that allows the water to be disaggregated into droplets, which form a small film that runs off the inner surface next to the plasma dart. The flame does not touch the small water film.

- Microwave plasma generator device. $(1 \mathrm{~kW})$

- Plasma hybrid filter collector with perfusion wall.

- Sample: Cyanide dissolution obtained from both head and tail of a gold treatment plant.

\section{B. Experimental procedure}

To estimate the radiant energy levels, we designed an experiment to measure the plasma thermal radiation's dissociation capacity, considering only the plasma dart's radiant emission on the sample and not the thermal gradient emission. The molecular dissociation energy value for $\mathrm{CN}^{-}$ bonds can be obtained from the Gibbs free energy (172.3 $\mathrm{KJ} / \mathrm{mol}$ ) [29]; therefore, we can deduce that to break the bonds of each molecule, at least $1.79 \mathrm{eV}$ should be applied. The strategy to optimize the molecular dissociation energy involves disaggregating the solution and adding $\mathrm{H}_{2} \mathrm{O}_{2}$ [26].

Afterward, the mixture of $\mathrm{CN}^{-}$and $\mathrm{H}_{2} \mathrm{O}_{2}$ is passed through a filter and it perfuses and percolates through the filter wall to form tiny drops of $\mathrm{CNO}^{-}$, which create a thin film that runs down the filter's internal wall and is then directly attacked by the plasma's radiant component. The Gibbs's free energy for the molecular dissociation of $\mathrm{CNO}^{-}$is $\Delta G=-98.7 \mathrm{KJ} / \mathrm{mol}$. Thus, to break the bonds of each molecule and accelerate the process, relatively less energy should be applied [29]. The lower Gibbs free energy value $\Delta \mathrm{G}$ for $\mathrm{CNO}^{-}$mentioned above and the lower energy required to dissociate molecules can be attributed to the fact that the thermodynamic system includes the remaining microwave energy used to produce plasma, which adds more entropy to the system before being attacked by black-body thermal radiation. Regarding this, we must consider the following equation:

$$
\Delta G_{(p, T)}=\Delta H-T \Delta S
$$

Where $\Delta \mathrm{H}$ is the enthalpy and $\Delta \mathrm{S}$ represents the entropy, enthalpy include all the energy sources added in the chamber. In this experiment, we found that at $6000{ }^{\circ} \mathrm{C}$, the microwavegenerated plasma source with a Wien law-deduced black-body irradiation of $2.6 \mathrm{eV}$ provide sufficient energy to dissociate substances. This could be considered as the release energy condition, which is enhanced by perfusion and percolation of the mixture through the filter wall.

As shown in the schematic of the reactor in Figure 2, a ceramic filter combined with a plasma radiation led to an interaction between whole-spectrum radiation and fluid charged with $\mathrm{CNO}^{-}$molecules. The filter design also prevents the power of the rays from being dispersed, ensuring that the interaction is basically over the $\mathrm{CN}^{-}$solution. The filter was almost transparent to microwaves and almost opaque to plasma irradiation. It could be considered as a kind of "mechanical disaggregating system" due to the perfusion/percolation phenomenon, which is based on the geometrical change of the volume of $\mathrm{CN}^{-}$solution passing through the cylindrical filter making a comparison with drops forming inside the filter. The area: volume ratio of the solution is sufficiently high when creating drops and watery percolated fronts inside and outside the filter respectively, forming a tiny front film (see Figure 3). This increases the possibility of photocatalyst interaction, UV absorption, reactive kinetics, and deposition of dissolved atoms on the surfaces as a layer-by-layer solution runs down the filter wall [30].

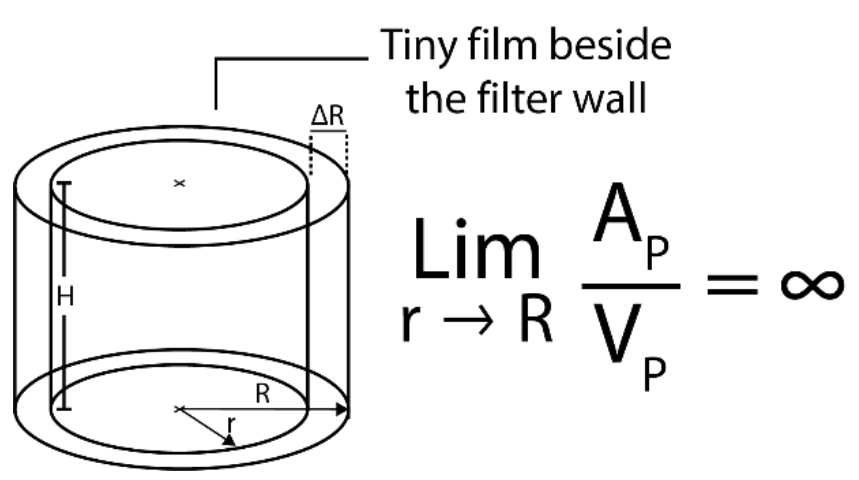

Fig. 3 A thin film of water forming an idealized infinitesimal cylinder after passing through the ceramic filter inside the reactor.

In practice, mining process use $\mathrm{H}_{2} \mathrm{O}_{2}$ for the elimination of cyanide, so spontaneously quantities of $\mathrm{NH}_{3}$ are produced, this

$1^{\text {th }}$ LACCEI International Multi-Conference for Engineering, Education, and Technology: "Innovation in Education and Inclusion", 19-21 July 2018, Lima, Peru. 
chemical species will serve as a means to demonstrate that in the same process and under conditions of adequate concentration and the application of specific plasma characteristics, for each molecular species processed, with our proposed technique, we will prove the condition of REACTOR-SPECIFIC MODEL (figure 1).

As a principle of our hypothesis, only with plasma radiation and the mechanical disaggregating system (figure 3) could we break down toxic bonds such as Cyanide producing carbon molecules but in the same sample with the presence of $\mathrm{NH}_{3}$ we can generate hydrogen, ingredients for the formation of hydrocarbon fuels " $\mathrm{C}_{\mathrm{x}}-\mathrm{H}_{\mathrm{y}}$ ", techniques for the production of $\mathrm{H}_{2}$ from $\mathrm{NH}_{3}$ have already been developed by others previously and it could be used as a concept for this work [31].

It should be noted that the same procedure could break down most toxic compounds, including $\mathrm{NO}_{\mathrm{x}}$ and $\mathrm{SO}_{\mathrm{x}}$, because they have Gibbs free energy levels below $2.0 \mathrm{eV}$ [15]; therefore, the presence of these compounds is not an issue inside a plasma reactor, where they do not have a significant presence. It should be considered that although $2.6 \mathrm{eV}$ corresponds to the Planck density peak at $6000{ }^{\circ} \mathrm{C}$, there is a "bandwidth" in which a spectral frequency can achieve values greater than $2.6 \mathrm{eV}$ with lower energy density and less probability of an interaction. In the plasma technique, the digestion reactor used an energy sink and included a hybrid UV filter [10] in which the samples ran down the ceramic filter wall (Figure 3). We prepared the samples by following the standard chemical technique used for detoxification [19] and employed the reaction of $\mathrm{CN}^{-}$and $\mathrm{H}_{2} \mathrm{O}_{2}$ having a ratio of 1:8 in concentration. We also tested a 1:12 ratio for some assays [20]. This technique was complemented by electrolysis to evaluate the effect of a voltage potential on the process. This setup (Figure 2) could release particles in a fluidized bed if gasification of raw material is chosen and then expose those particles to the plasma thermal dart or plasma made of electrons accelerated by an ionizing potential [32].

\section{Assays}

- First Test

Sample: Detoxification of wastewater from a mine tailing Main target: $\mathrm{CN}^{-}$

Detoxification action: Exposing samples to UV irradiation with 470-nm-wavelength lamps and comparing the samples with those subjected to a plasma spectrum at $6000{ }^{\circ} \mathrm{C}$ (in the system shown in Figure 2 with a perfusion/percolation wall).

Sample volume: $1 \mathrm{~L}$ (This volume will be standard for all experiments).
M1: Sample exposed to irradiation using two UV lamps (25 W at $470 \mathrm{~nm}$ )

Sample concentration alimentation solution: $1.60 \mathrm{ppm}$

Condition: Downstream water in a layer exposed to UV light.

Flux residence time: $30 \mathrm{~min}$.

M2: Sample subjected to the plasma method

Sample concentration: $1.60 \mathrm{ppm}$

Flux residence time: $5 \mathrm{~min}$

Condition: Downstream water in a layer exposed to plasma radiation dart (Figure 2). Results in TABLE I

\section{- Second Test}

Assay: A sample circulates through the microwave plasma generator with a hybrid filter device and a collector with a perfusion wall. Passed four times through the reactor.

Sample concentration: $1.09 \mathrm{ppm}$

Flux residence time: $20 \mathrm{~min}$

Condition: Downstream water in a layer exposed to plasma radiation dart (Figure 2). Results in TABLE II.

- Third Test

Assay: Two samples of the same concentration are tested, and each sample circulates through a microwave plasma generator with a hybrid filter device (Figure 2) once. One of the samples is also treated using electrolysis

Sample concentration: 459.26 ppm

Output 1: UV from plasma

Output 2: UV plasma + electrolysis

Residence time flux: $20 \mathrm{~min}$. Results in TABLE III.

- Fourth Test

Assay: A sample circulates through the microwave plasma generator with a hybrid filter device and a collector with a perfusion wall. This sample will serve for next test to evaluate $\mathrm{NH}_{3}$.

Flux residence time: $10 \mathrm{~min}$

Sample concentration: 1.593 ppm. Results in TABLE IV.

- $\quad$ Fifth Test

Assay: the sample used in Fourth test will serve for this step to evaluate $\mathrm{NH}_{3}$.

Flux residence time: $10 \mathrm{~min}$

Sample concentration: 1.593 ppm

Condition: This test evaluate the $\mathrm{H} 2$ production through the increase or decrease of the $\mathrm{N}-\mathrm{NH}_{3}$ and $\mathrm{N}-\mathrm{NO}_{3}$ species. Results in TABLE V. 


\section{TABLE I}

Water treatment results after irradiation. M1: sample exposed to radiation from ultraviolet lamps, M2: sample subjected to the plasma method. A colorimetric method is used to measure the cyanide concentration.

\begin{tabular}{|c|c|c|c|c|c|c|c|c|c|}
\hline \multicolumn{10}{|c|}{ First Test } \\
\hline Sample & $\begin{array}{c}C N T \\
{\left[m g L^{-1}\right]}\end{array}$ & $\begin{array}{c}C N W \\
{\left[m g L^{-1}\right]}\end{array}$ & $P h$ & $\begin{array}{c}C u \\
{\left[m g L^{-1}\right]}\end{array}$ & $\begin{array}{c}F e \\
{\left[m g L^{-1}\right]}\end{array}$ & $\begin{array}{c}Z n \\
{\left[m g L^{-1}\right]}\end{array}$ & $\begin{array}{c}P b \\
{\left[m g L^{-1}\right]}\end{array}$ & $\begin{array}{c}T S S \\
{\left[m g L^{-1}\right]}\end{array}$ & $m V$ \\
\hline$M 1$ & 1.493 & 1.037 & 9.78 & 10.98 & 0.02 & 0.06 & 0.16 & 91 & 159.9 \\
\hline$M 2$ & 0.95 & 0.535 & 9.75 & 9.09 & 0.02 & 0.04 & 0.28 & 172 & 157.6 \\
\hline
\end{tabular}

\section{TABLE II}

Water treatment through the microwave plasma generator with a hybrid filter device. A colorimetric method is used to measure the cyanide concentration. Flux residence time: 20 min.

\begin{tabular}{|c|c|c|c|c|c|}
\hline \multicolumn{5}{|c|}{ Second Test } \\
\hline Parameter & Methodology & $\begin{array}{c}\text { Limited } \\
\text { Quantification }\end{array}$ & Unity & $\begin{array}{c}\text { Alimentation } \\
\text { Solution }\end{array}$ & $\begin{array}{c}\text { Production } \\
\text { Solution }\end{array}$ \\
\hline Total Cyanide & $\begin{array}{c}\text { SM 4500-CN }- \text { C, E. } \\
\text { Cyanide. Total Cyanide } \\
\text { after Distillation. } \\
\text { Colorimetric Method }\end{array}$ & $\mathbf{0 . 0 0 5}$ & {$\left[\mathrm{mgL}^{-1}\right]$} & 1.09 & $<0.005$ \\
\hline Wad Cyanide & $\begin{array}{c}\text { SM 4500-CN - I, E. } \\
\text { Cyanide. Weak Acid } \\
\text { Dissociated Cyanide. } \\
\text { Colorimetric Method }\end{array}$ & $\mathbf{0 . 0 0 5}$ & {$\left[\mathrm{mgL}^{-1}\right]$} & $\mathbf{0 . 7}$ & $<0.005$ \\
\hline
\end{tabular}

TABLE III

Water treatment through the microwave plasma generator with a hybrid filter device, Output 1: UV(P)-3a. Output 2: $\mathrm{UV}(\mathrm{P})-3 \mathrm{~b}$ is also treated using electrolysis. A colorimetric method is used to measure the cyanide concentration. Residence time: $20 \mathrm{~min}$.

\begin{tabular}{|c|c|c|c|c|c|c|c|c|c|}
\hline \multicolumn{10}{|c|}{ Third Test } \\
\hline Sample & $\begin{array}{c}C N T \\
{\left[m g L^{-1}\right]}\end{array}$ & $\begin{array}{c}C N W \\
{\left[m g L^{-1}\right]}\end{array}$ & $P h$ & $\begin{array}{c}C u \\
{\left[m g L^{-1}\right]}\end{array}$ & $\begin{array}{c}F e \\
{\left[m g L^{-1}\right]}\end{array}$ & $\begin{array}{c}Z n \\
{\left[m g L^{-1}\right]}\end{array}$ & $\begin{array}{c}P b \\
{\left[m g L^{-1}\right]}\end{array}$ & $\begin{array}{c}T S S \\
{\left[m g L^{-1}\right]}\end{array}$ & $m V$ \\
\hline$Z 2-3$ & 459.26 & 350.31 & 9.77 & 78.44 & 42.92 & 140.8 & 0.1 & 107 & -145.7 \\
\cline { 2 - 11 } & 2.02 & 1.26 & 9.79 & 5.93 & 0.17 & 0.1 & $<0.02$ & 34 & -145.5 \\
$U V(P)-3 b$ & 7.73 & 6.13 & 9.81 & 6.9 & 0.6 & 0.03 & $<0.02$ & 175 & -146.1 \\
\hline
\end{tabular}

$1^{\text {th }}$ LACCEI International Multi-Conference for Engineering, Education, and Technology: "Innovation in Education and Inclusion", 19-21 July 2018, Lima, Peru. 


\section{TABLE IV}

Water treatment through the microwave plasma generator with a hybrid filter device. A colorimetric method is used to measure the cyanide concentration. Residence time: $10 \mathrm{~min}$.

\begin{tabular}{|c|c|c|c|c|c|}
\hline \multicolumn{6}{|c|}{ Fourth Test } \\
\hline Parameter & Methodology & $\begin{array}{c}\text { Limited } \\
\text { Quantification }\end{array}$ & Unity & $\begin{array}{c}\text { Alimentation } \\
\text { Solution }\end{array}$ & $\begin{array}{c}\text { Production } \\
\text { Solution }\end{array}$ \\
\hline $\begin{array}{c}\text { Total } \\
\text { Cyanide }\end{array}$ & $\begin{array}{c}\text { SM } 4500-C N-C, E . \\
\text { Cyanide. Total Cyanide after } \\
\text { Distillation. Colorimetric } \\
\text { Method }\end{array}$ & 0.005 & {$\left[m g L^{-1}\right]$} & 1.593 & 0.407 \\
\hline
\end{tabular}

\section{TABLE V}

A Selective Electrode Method for analysis of Nitrogen - Ammonia.

\begin{tabular}{|c|c|c|c|c|}
\hline \multicolumn{5}{|c|}{ Fifth Test } \\
\hline Parameter & Methodology & $\begin{array}{l}\mathrm{NO}_{3^{-}}-\mathrm{N} \\
{\left[\mathrm{mgL}^{-1}\right]}\end{array}$ & $\begin{array}{l}\mathrm{N}-\mathrm{NH}_{3} \\
{\left[\mathrm{mgL}^{-1}\right]}\end{array}$ & $\begin{array}{c}\mathrm{NH}_{3} \\
{\left[\mathrm{mgL}^{-1}\right]}\end{array}$ \\
\hline Alimentation Solution & Nitrogen (Ammonia), Ammonia & 14.5 & 310.99 & 378.13 \\
\hline Production Solution & Selective Electrode Method & 15.5 & 218.99 & 266.27 \\
\hline
\end{tabular}

\section{RESULTS AND DISCUSSION}

\section{A. Data analysis}

Table 1 summarizes the results after irradiation, where $\mathrm{CNT}$ is the total $\mathrm{CN}^{-}$concentration, $\mathrm{CNW}$ is the $\mathrm{CN}^{-}$weak acid dissociable concentration (CNWAD), TSS is the total suspended solids ( $\mathrm{Cu}, \mathrm{Fe}, \mathrm{Zn}$, and $\mathrm{Pb}$ ions), and $\mathrm{mV}$ is the redox potential.

The first test was a control test following the recommendation of the German Environmental Control Office for treating $\mathrm{CN}^{-}$waste [17]. In procedure $\mathrm{M} 1$ the results of this test revealed that UV irradiation by two $25-\mathrm{W}, 470-\mathrm{nm}$ lamps reduced the $\mathrm{CN}^{-}$concentration from 1.60 to $1.49 \mathrm{ppm}$ in $30 \mathrm{~min}$, whereas in procedure $\mathrm{M} 2$ using full-spectrum plasma radiation reduced the $\mathrm{CN}^{-}$concentration from 1.60 to $0.95 \mathrm{ppm}$ in $5 \mathrm{~min}$. In the first case, when a low $\mathrm{H}_{2} \mathrm{O}_{2}$ concentration and downstream water condition were employed, there was a relatively low performance, i.e., a $6 \%$ reduction in the $\mathrm{CN}^{-}$ concentration, compared with a slurry stationary assay reported as a reference $[19,20]$.
The $\mathrm{CN}^{-}$concentration decreased by $\sim 40 \%$ solely with plasma and $5 \mathrm{~min}$ of residence time inside the reactor. In the second test, $\mathrm{CN}^{-}$was not detected at all. We used a colorimetric method to measure the $\mathrm{CN}^{-}$concentration. The instrument sensitivity was $0.005 \mathrm{ppm}$. Here the total process time was 20 minutes.

In the third test, a high CNT concentrating sample as alimentation solution was analyzed, by thermal plasma radiation, the CNT concentration decreased from 459.26 to 7.73 ppm, i.e., by $\sim 98 \%$, indicating that this technique is an efficient way to eliminate toxic compounds. In this test, the destruction of $\mathrm{CN}^{-}$bonds occurred due to mechanical disaggregation through the filter, followed by molecular dissociation via plasma radiation.

After this test, the sample was subjected to an electrolysis test at 6 Volt, 7 amperes, obtaining an additional reduction of 7.73 to $2.02 \mathrm{ppm}$. In this test it can be found an important concentration reduction in all others complex compounds. This could be attribute a special Ceramic Porous percolation system showed in figure 2, which it works as a "mechanical disaggregating system" and as a cations and anions filter.

$1^{\text {th }}$ LACCEI International Multi-Conference for Engineering, Education, and Technology: "Innovation in Education and Inclusion", 19-21 July 2018, Lima, Peru. 
In all cases, the $\mathrm{CN}^{-}$and $\mathrm{CNWAD}$ concentrations were significantly reduced using the plasma technique. These results lay the groundwork for initiating a pilot test to achieve massive production using this procedure.

Fourth and Fifth test have been done with the same sample, with initial CNT concentration of $1.593 \mathrm{ppm}$ and after 10 minutes of processing it can be seen the reduction of CNT concentration to a $0.407 \mathrm{ppm}$. With the data found until this test a graph showed in figure 4 was built.

Fifth test it has a special meaning because prove the REACTOR- SPECIFIC MODEL (figure 1) where with a sample which it has basic compounds $\mathrm{CN}^{-}$and $\mathrm{NH}_{3}$, these can be separated by plasma radiation only. Breaking chemical bonding by means of Black Body Radiation generated by plasma between 5000 and 6000 degrees is possible using the "mechanical disaggregating system" concept properly.

As can be seen in Fifth test, the fact that $\mathrm{NO}_{3}-\mathrm{N}$ raise and the reduction in $\mathrm{NH}_{3}$ and $\mathrm{N}-\mathrm{NH}_{3}$ concentration it means the breaking of bondings of Nitrogen and the release and formation of $\mathrm{H}_{2}$ which is gasificated and should be required the quantification of this production in further measurements. It can be seen that in 10 minutes with the application of plasma radiation the concentration of $\mathrm{NH} 3$ reaches from 378.13 to $266.27 \mathrm{ppm}$, this result represents a decrease of $30 \%$ which could have an important slope down curve in a longer time of exposure to plasma radiation in combination with the mechanical disaggregation.

Our proposed method can possibly dissociate molecules using plasma energy without the direct action of a plasma thermal component. To adjust the plasma spectra temperature for dissociating the chemical bonds, we only need to know the dissociation energies of the involved molecules, which are available in the literature and in chemistry tables. To perform sample transformation, one should decide to use either the thermal dart or radiation energy to split out the weak chemical links, thereby avoiding the unsuitable use of the complete plasma energy as disaggregation energy.

We also tested the effect of electrolysis in the system as support media $\left(\mathrm{CN}^{-}\right.$concentration decreased from 7.73 to 2.02 ppm; refer to the third test in Table 1). This was done to establish a correlation between liquid and vapor states when processing solid waste in a low-energy thermal fluidized bed with volatile products is necessary, where we can use accelerated electrons from plasma at $70 \mathrm{eV}$ [32] which it's too easy to implement in a chamber where several plasma forms could exist at atmospheric pressure.

Figure 4 shows a plot of $\mathrm{CN}^{-}$concentration vs. plasma irradiation time, indicating a decrease in the $\mathrm{CN}^{-}$concentration as the irradiation residence time increased. After $\sim 20 \mathrm{~min}, \mathrm{CN}^{-}$ was eliminated.

\section{B. Graph obtained from test}

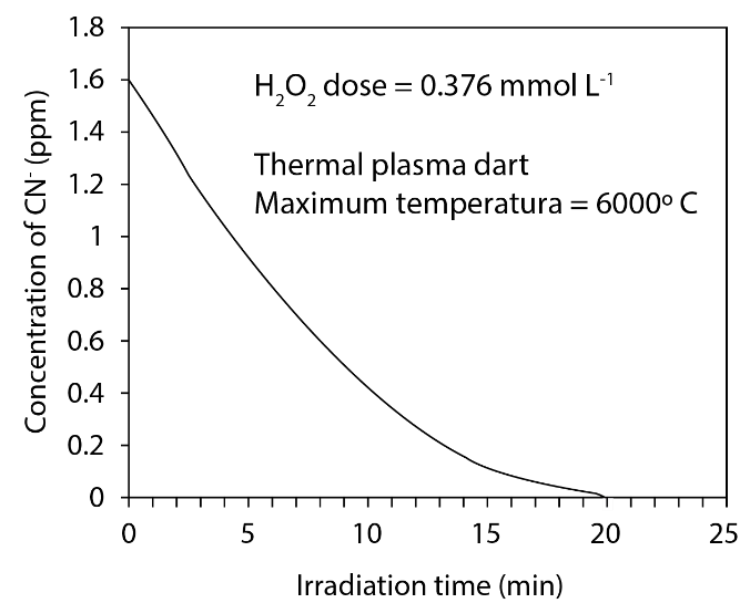

Fig. 4 Photo - oxidation and degradation of cyanide using plasma radiation from black body spectrum at $6000 \mathrm{C}$. A percolation disaggregating filter was used.

The amount of $\mathrm{H}_{2} \mathrm{O}_{2}$ employed was lower than that used in other procedures with UV lamps; therefore, we could reduce the quantity of $\mathrm{H}_{2} \mathrm{O}_{2}$ until we find a suitable value for a given $\mathrm{CN}^{-}$ concentration and plasma generator power.

\section{CONCLUSIONS}

The plasma radiation method complemented by mechanical disaggregation through a perfusion/percolation process is a powerful tool for water detoxification as it breaks apart $\mathrm{CN}^{-}$molecules due to the rise of the interaction photocatalytic parameters which is justified with the Area/volume ratio according the nano and supra-nano interaction theory, saving energy by molecular disaggregating processes. Herein, we proposed a reactor design to transform waste materials into harmless materials to eliminate toxic substances in water and produce energy considering the compounds and physical chemical characteristics of the sample. Our experimental findings revealed that different plasma source characteristics can be used to break bonds by optimizing energy generation and application on specific bonds in either native or transformed substances. The reactor-specific model shown in Figure 2 efficiently used each energetic requirement, optimizing the aggregation and dissociation processes and acquiring a correlation between the liquid and vapor phases.

The next step in our research was to improve the electrical power efficiency. We primarily aimed to assess the response of plasma irradiation, followed by a porous percolation process inside a small chamber. We also anticipated to reduce the interaction space between irradiation and $\mathrm{CN}^{-}$molecules. Reactors that degrade a large amount of $\mathrm{CN}^{-}$using conventional UV lamps require a considerably large space to set up an arrangement of multiple lamps. This could be the

16 $^{\text {th }}$ LACCEI International Multi-Conference for Engineering, Education, and Technology: "Innovation in Education and Inclusion", 19-21 July 2018, Lima, Peru. 
chance to transform energy from the dissociated elements in clean way choosing correctly the raw material necessary to recombine it into fuel species inside a suitable transformation chamber.

For future projects, using the proposed technique in combination with catalytic elements for the construction of the filter used for the mechanical disaggregation of samples could improve the yield in the destruction of pollutants and in the production of carbon and hydrogen for their recombination in hydrocarbon species.

\section{ACKNOWLEDGEMENTS}

To the company REDISUENER TECHNOLOGIES SAC that offered its patented equipment "Digestion Reactor by energy Sink" and "water hybrid treatment by plasma system" for the development of this test. To TECIN MINERA SAC for support with the facilities and lab assays to INDECOPI, which granted the patent in due time. Finally, to National Engineering University mainly to the Doctoral Energetic Program and the professional team who leadership the academic cathedra.

\section{REFERENCES}

[1] Fugiel, A., Burchart-Korol, D., Czaplicka-Kolarz, K., \& Smoliński, A. (2017). Environmental impact and damage categories caused by air pollution emissions from mining and quarrying sectors of European countries. Journal of Cleaner Production, 143, 159-168.

[2] Luque-Almagro, V. M., Moreno-Vivián, C., \& Roldán, M. D. (2016). Biodegradation of cyanide wastes from mining and jewellery industries. Current opinion in biotechnology, 38, 9-13.

[3] Nations Encyclopedia. Peru - Environment, http://www.nationsencyclopedia.com/Americas/PeruENVIRONMENT.html/; 2014 [accessed 1 October 2017].

[4] Yakovleva, N. Corporate social responsibility in the mining industries. Routledge; 2017.

[5] Li, Z., Ma, Z., van der Kuijp, T. J., Yuan, Z., \& Huang, L. (2014). A review of soil heavy metal pollution from mines in China: pollution and health risk assessment. Science of the Total Environment, 468, 843-853.

[6] Lopez, I., \& Borzacconi, L. (2000). Final disposition of municipal solid waste: need for an integral approach. Ingenieria Quimica, (18), 45-52.

[7] Heller, L., \& Catapreta, C. A. A. (2003). Solid waste disposal in urban areas and health-the case of Belo Horizonte, Brazil. Waste management \& research, 21(6), 549-556.

[8] Krook, J., \& Baas, L. (2013). Getting serious about mining the technosphere: a review of recent landfill mining and urban mining research. Journal of Cleaner Production, 55, 1-9.

[9] Valmundsson, A. S., \& Janajreh, I. (2011, August). Plasma gasification process modeling and energy recovery from solid waste. In 5th international conference on energy sustainability, Washington, USA.

[10] F. d. Valencia, International Patent No. WO2015080604. (2015).

[11] Lupa, C. J., Wylie, S. R., Shaw, A., Al-Shamma'a, A., Sweetman, A. J., \& Herbert, B. M. (2013). Gas evolution and syngas heating value from advanced thermal treatment of waste using microwave-induced plasma. Renewable energy, 50, 1065-1072.

[12] Gleizes, A. (2015). Perspectives on thermal plasma modelling. Plasma Chemistry and Plasma Processing, 35(3), 455-469.
[13] Mountouris, A., Voutsas, E., \& Tassios, D. (2006). Solid waste plasma gasification: equilibrium model development and exergy analysis. Energy Conversion and Management, 47(13), 1723-1737.

[14] Darwent, B. D. (1970). Bond dissociation energies in simple molecules. NSRDS-NBS NO. 31, U. S. DEPT. COMMERCE, WASHINGTON, D. C. JAN. 1970, 48 P.

[15] Hinshelwood, C. N. Aggregation of Molecules to Solids and Liquids. In: Oxford University Press on Demand, editors. The structure of physical chemistry. USA; 2005, p. 71-94.

[16] Taboada-González, P., Aguilar-Virgen, Q., \& Armijo-de Vega, C. (2009). La tecnología de plasma y residuos sólidos. Ingeniería, 13(2).

[17] Enviolet. Degradación del cianuro, http://www.enviolet.com/es/oxidacion-ultravioleta-uv/oxidacionultravioleta-uv/degradacion-del-cianuro.html [accessed 27 February 2018].

[18] Dash, R. R., Gaur, A., \& Balomajumder, C. (2009). Cyanide in industrial wastewaters and its removal: a review on biotreatment. Journal of Hazardous Materials, 163(1), 1-11.

[19] Malhotra, S., Pandit, M., Kapoor, J. C., \& Tyagi, D. K. (2005). Photooxidation of cyanide in aqueous solution by the UV/H2O2 process. Journal of Chemical Technology and Biotechnology, 80(1), 13-19.

[20] Sarla, M., Pandit, M., Tyagi, D. K., \& Kapoor, J. C. (2004). Oxidation of cyanide in aqueous solution by chemical and photochemical process. Journal of Hazardous Materials, 116(1), 49-56.

[21] Fridman, A. (2008). Plasma chemistry. Cambridge university press.

[22] Li, J., Liu, K., Yan, S., Li, Y., \& Han, D. (2016). Application of thermal plasma technology for the treatment of solid wastes in China: an overview. Waste Management, 58, 260-269.

[23] Gomez, E., Rani, D. A., Cheeseman, C. R., Deegan, D., Wise, M., \& Boccaccini, A. R. (2009). Thermal plasma technology for the treatment of wastes: a critical review. Journal of Hazardous Materials, 161(2), 614-626.

[24] Zhukov, M. F., \& Zasypkin, I. M. (Eds.). (2007). Thermal plasma torches: Design, characteristics, application., Cambridge Int Science Publishing.

[25] Shin, D. H., Hong, Y. C., Lee, S. J., Kim, Y. J., Cho, C. H., Ma, S. H., ... \& Uhm, H. S. (2013). A pure steam microwave plasma torch: Gasification of powdered coal in the plasma. Surface and Coatings Technology, 228, S520-S523.

[26] Olleros, J. C. (2013). Aplicación de la fotocatálisis solar a la degradación de contaminantes orgánicos en fase acuosa con catalizadores nanoestructurados de $\mathrm{TiO} 2$ (Doctoral dissertation, Universidad Autónoma de Madrid).

[27] Vigil, E., Zumeta, I., Ayllón, J. A., \& Espinosa, R. Obtención de hidrógeno por fotólisis: un reto para la tecnología y ciencia de los materiales. Facultad de Física-Instituto de Materiales y Reactivos, Univ. de La Habana.

[28] Pedemonte, M. M. (2011). Estudios fisicoquímicos sobre materiales basados enel $\mathrm{TiO} 2$ relacionados con la foto-descomposición del agua y el desarrollo de celdas solares fotoelectroquímicas (Doctoral dissertation, Facultad de Ciencias Exactas).

[29] Domínguez, J. C. P., \& Cobos, O. F. H. (2008). Análisis termodinámico de especies cianuradas de oro, plata y cobre sometidas a cementación con zinc y aluminio. Scientia et technica, 14(38), 155160 .

[30] Cobo, E. R. (2012). Síntesis, propiedades y funcionalización de clústeres metálicos (Doctoral dissertation, Universidade de Santiago de Compostela).

[31] Gil, S. A. (2012). Síntesis de catalizadores estructurados de Ni y Ru soportados sobre monolitos cerámicos recubiertos de alúmina o nanofibras de carbono y su aplicación en la producción de $\mathrm{H} 2$ mediante la descomposición de NH3 (Doctoral dissertation, Universidad de Zaragoza)

[32] Stashenko, E. E., \& Martínez, J. R. (2009). Aspectos prácticos de la ionización con electrones en la obtención de espectros de masas y su interpretación. Scientia Chromatographica, 1(4), 19-36.

$16^{\text {th }}$ LACCEI International Multi-Conference for Engineering, Education, and Technology: "Innovation in Education and Inclusion", 19-21 July 2018, Lima, Peru. 